\title{
Environmental Characteristics by Eco-Sanitary and Toxic Criteria of the Cooling Pond of Zaporizhzhya Nuclear Power Plant (Ukraine)
}

\author{
Olena Fedonenko*, Tamila Ananieva, Tetiana Sharamok, Oleh Marenkov \\ Oles Honchar Dnipro National University, Faculty of Biology and Ecology, \\ Department of General Biology and Water Bioresources \\ P.M.B. 49050, Dnipro, Ukraine \\ hydro-dnu@mail.ru
}

\begin{abstract}
Keywords: Cooling pond, hydrophysical and hydrochemical indicators, toxic metals, water, bottom sediments, ecological assessment of water quality.
\end{abstract}

\begin{abstract}
It has been investigated the ecological status of the cooling pond of Zaporizhzhya Nuclear Power Plant (NPP) on the hydrochemical and toxicological indicators. The ecological water quality by most hydrochemical and hydrophysical indices corresponds to the class II, category 3 , and is characterized as "fairly clean". However, according to the $\mathrm{BOD}_{5}$ index, the water quality is "satisfactory" (class III, category 4). By the contents of both nitrogen of nitrates and phosphorus of phosphates the water quality belongs to the class IV, category 6, as "bad, dirty water". The main anthropogenic pollutants are copper, iron, zinc, and fluorides. The ecological characteristics by their concentrations in the water correspond to the class III, and categories 4-5 of quality, which are "poorly and moderately polluted" water. Accumulation of toxic metals in the surface layer of the reservoir bottom sediments depends on their types, the minimal content is found in sandy sediments, and maximal one is in muddy sediments. The possibility of significant secondary pollution of the water environment by toxic metals is small under the hydrophysical and hydrochemical conditions typical for the cooling pond of Zaporizhzhya NPP. According to the calculations, the value of the average chemical index of ecological quality is " 2.5 ", which characterizes the water of the Zaporizhzhya NPP cooling pond as "good" and "clean".
\end{abstract}

\section{Introduction}

The cooling pond of Zaporizhzhya Nuclear Power Plant (NPP) because of additional heat from cooling systems of power units belongs to water bodies with an unusual thermal water regime for natural waters [1]. In terms of heat load a special thermal, hydrochemical and hydrobiological regime has formed in ecosystem that determines the migration of chemical elements and their bioavailability for organisms and ability to biodegradation, transformation and accumulation in sediments. Physical and chemical conditions of the water environment in the cooling ponds, which formed due to significant thermal loads, contribute to the development of sorption processes of toxic metals in suspended solids, hydrolysis, precipitation and co-precipitation that under conditions of slow flow leads to the withdrawal of toxic metals from the water environment and their accumulation in bottom sediments.

Bottom sediments in reservoirs with slower water exchange are able to accumulate actively chemicals of different nature, including those with pronounced toxic properties [2]. Accumulation of substances in the bottom sediments of natural reservoirs is one of the reasons for their partial or complete withdrawal from the cycle and self-purification of the aquatic environment. However, in certain circumstances the probability of contamination of the water mass that is in contact with the bottom sediments is preserved [3].

It is known that the toxicity and bioavailability of metals depends a lot on their form in water and in the bottom sediments $[4 ; 5]$. The main factors determining the processes of migration of substances from the bottom sediments into water are the diffusion of porous solutions, desorption and complex formation. Complex formation with organic substances regulates interphase distribution of elements in natural waters as it determines the nature of the interaction at the "water - suspended solids" and "water - bottom sediments" interphase boundaries [6]. 
The results of hydroecological research should serve as the basis for developing the methodology and principles of environmental management, increasing hydroecological safety and optimizing the functioning of NPPs [7]. Technogenic cooling ponds are included in the surface water basins, the environmental quality assessments of which are relevant all over the world [8; 9].

The purpose of the work was determining the ecological status of the cooling pond of Zaporizhzhya Nuclear Power Plant on the basis of hydrochemical and toxicological indicators.

\section{Materials and Methods}

\section{Study site}

Zaporizhzhya NPP is the largest energy facility in Ukraine and Europe with an installed capacity of $6000 \mathrm{MW}$. From 1984 to 1995, six power units were put into operation; its contribution to the energy sector of Ukraine is $22 \%$.

The cooling pond of Zaporizhzhya NPP $\left(47^{\circ} 30^{\prime} 49.2^{\prime \prime} \mathrm{N} 34^{\circ} 33^{\prime} 05.3^{\prime \prime} \mathrm{E}\right)$ belongs to the lakepond type (Fig. 1). The type of regulation of the level regime is seasonal. The cooling pond is constructed by cutting off the part of the Kakhovka reservoir by alluvial sandy dam and has the following parameters: the area of the mirror is $8.2 \mathrm{~km}$, the volume is 47.05 million $\mathrm{m}^{3}$, the average depth is $5.87 \mathrm{~m}$, the maximum depth is $13.5 \mathrm{~m}$, and the length of coast line is $11.2 \mathrm{~km}$.

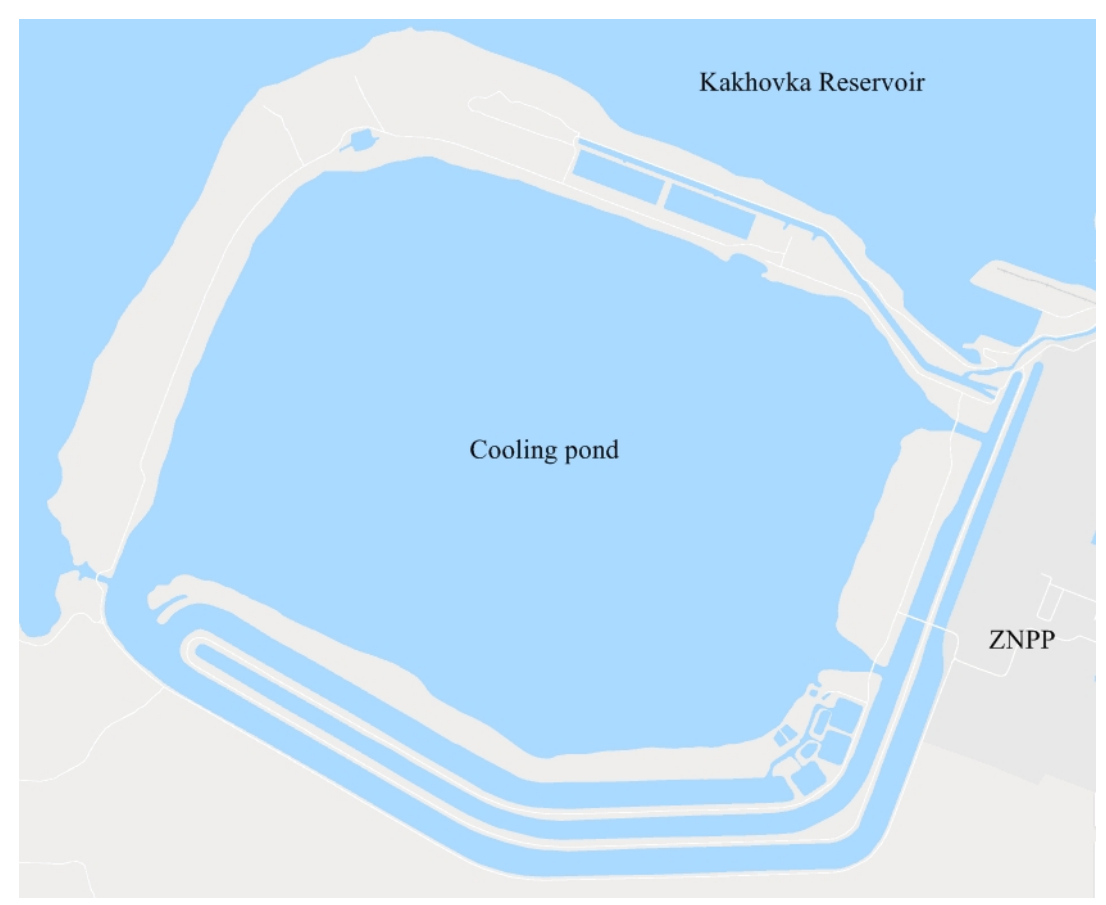

Figure 1. The location scheme of the cooling pond of Zaporizhzhya NPP (ZNPP); Google map, $47^{\circ} 30^{\prime} 49.2^{\prime \prime} \mathrm{N} 34^{\circ} 33^{\prime} 05.3^{\prime \prime} \mathrm{E}$

The water supply and cooling system of Zaporizhzhya NPP is quite complicated. The water from the Kakhovka reservoir enters system, which passes through the water supply systems of the Zaporizhzhya TPP. Then water enters the heat sink, along the supply channel to the power units, then into the outlet, spray devices, two cooling towers, and as the system operates almost continuously, the water returns to the Kakhovka reservoir again. The average temperature of the cooled water in the pond during the hottest month of the year is $28.7^{\circ} \mathrm{C}$. In the winter months, the water temperature is $17-18^{\circ} \mathrm{C}$. There is not an ice cover on the cooling pond in winter period.

The technical water supply of Zaporizhzhya NPP is reversible. The joint use of such hydrotechnical structures as the heat sink, spray pools, and cooling towers, allows the combination of the maneuverability and inertia of the coolers in the changing meteorological conditions. This scheme has no analogues in Ukraine and is considered as experimental one. 
An effective part of the Zaporizhzhya NPP safe operation is fish stocking the cooling pond, since the species of fish used for biomelioration (grass carp and black carp, silver carp) help to reduce overgrown and amount of blue-green algae and mollusks. The nuclear power plant with the cooling pond is a single interconnected system and the stocking program allows maintaining the standard parameters of the hydrobiological regime of the cooling pond.

\section{Water and Bottom Sediments Sampling}

Water samples for hydrochemical and toxicological analysis were selected every month during 2017 in the surface layer.

Preparation of water samples for toxicological analysis was following: water was filtered through a $0.45 \mu \mathrm{m}$ membrane filter to separate the suspended solids, acidified with especially pure hydrochloric acid to $\mathrm{pH}=2.5$ and stored for laboratory treatment. Subsequently, 1 liter sample of water was evaporated to dryness, after which the residue was dissolved in $1 \mathrm{~N}$ nitric and $1 \mathrm{~N}$ hydrochloric acid.

Samples of bottom sediments were taken from the horizon of $0-5 \mathrm{~cm}$. During preparation for analysis, the samples were dried at $105^{\circ} \mathrm{C}$ to a constant weight, and then were burned to a white ash at $450^{\circ} \mathrm{C}$, which was treated with $1 \mathrm{~N}$ nitric and $1 \mathrm{~N}$ hydrochloric acid. The resulting solution was filtered through a "blue ribbon" filter and transferred to containers and its volume was $10 \mathrm{ml}$.

\section{Hydrochemical and Toxicological Analysis}

The hydrochemical studies were conducted according to standard methods [10]. The content of toxic metals in the sample was determined on a spectrophotometer C-115M1 [11]. Totally, 120 samples of water and bottom sediments were analyzed. Indicators of the chemical composition of water were compared with the normative criteria of water quality for fishery needs (SOU 05.01-37385: 2006; DSTU 2284: 2010) [12; 13].

The bottom accumulation coefficient (BAC) was calculated as:

$$
K=\frac{C s}{C w},
$$

where $C s$ - concentration of pollutants in bottom sediments or hydrobionts; $C w$ - concentration of pollutants in water.

The value of the chemical water quality index ( $\left.I_{\text {Xaverage }}\right)$ was calculated as:

$$
I_{\text {Xaverage }}=\left(I_{\text {Saverage }}+I_{T \text { Caverage }}+I_{\text {Taverage }}\right) / 3 \text {, }
$$

where $I_{\text {Saverage }}$ - index of indicators of salt composition; $I_{T C \text { average }}$ - index of chemical trophicsaprobiological (ecological and sanitary) indicators; $I_{\text {Taverage }}-$ index of specific toxicity indicators.

Environmental assessment of water quality in different categories was carried out in accordance with the methodology based on the Common Implementation Strategy for the Water Framework Directive (2000/60/EC), Guidance document № 10 (2003), and method of Romanenko et al., 1998-2001 [14-16]. The obtained results were mathematically processed by standard methods of variation statistics using the Microsoft Excel-2010 program.

\section{Results and Discussion}

Hydrochemical regime of artificial water bodies is similar in basic features to that in natural waters in the same climate zone. However, the typical thermal regime of cooling pond contributes to conditions in which there is more intense evaporation of water compared to natural waters. In turn that increases the rate of mineralization [17; 18]. Against the background of abnormally high temperature of water, in some cooling ponds there is a tense gas regime, primarily the regime of dissolved oxygen in the water, which negatively affects their fishery conditions. In the investigated water facility, there is also a seasonal decrease in the content of dissolved oxygen, but its level in the summer does not decrease below $6.0 \mathrm{mg} / \mathrm{L}$, which satisfies to the fishery regulations. The inflow 
of large amounts of heated water into the cooling pond can contribute to the displacement of carbonate-calcium equilibrium and changes in the $\mathrm{pH}$ value. According to our data, in the autumn period there was a shift in the values of the active reaction of water to the alkaline side, $\mathrm{pH}=9.45$ (Table 1).

Table 1. Hydrophysical and general hydrochemical characteristics of the cooling pond of Zaporizhzhya NPP

\begin{tabular}{|c|c|c|}
\hline Name of the indicator, units of measurement & Measured value & National Standard [12; 13] \\
\hline Temperature, ${ }^{\circ} \mathrm{C}$ & $25.3 \pm 2.56$ & not more than 28 \\
\hline Hydrogen index, units of $\mathrm{pH}$ & $7.9 \pm 0.5$ & $6.5-8.5$ \\
\hline Transparency, $\mathrm{cm}$ & $>31$ & $75-1000$ \\
\hline Suspended matters, $\mathrm{mg} / \mathrm{L}$ & $<5.0 \pm 0.65$ & not more than 25.0 \\
\hline Dissolved oxygen, $\mathrm{mg} / \mathrm{L}$ & $7.08 \pm 0.18$ & not less than 5.0 \\
\hline Mineralization on dry matter, $\mathrm{mg} / \mathrm{L}$ & $403.0 \pm 7.13$ & 1000 \\
\hline
\end{tabular}

The salinity of the water completely meets the criteria of the fishery regulations (Table 2).

The shift in carbonate-calcium equilibrium under the influence of a significant amount of heated water is one of the specific features of water in cooling ponds. Generally, water masses of artificial reservoirs, primarily cooling ponds, are characterized by water saturation with calcium carbonate, which in turn is a prerequisite and a reason for the formation of carbonate deposits on heat-exchange surfaces. On the other hand, the content of $\mathrm{Ca}^{2+}$ is limited by its consumption by hydrobionts, especially in the process of the formation and growth of shells of mollusks.

Table 2. The contents of some main ions in water of the cooling pond of Zaporizhzhya NPP

\begin{tabular}{|c|c|c|}
\hline Name of the indicator, units of measurement & Measured value & National Standard [12; 13] \\
\hline Sodium and Potassium, $\mathrm{Na}^{+}+\mathrm{K}^{+}, \mathrm{mg} / \mathrm{L}$ & $30.1 \pm 0.72$ & 50 \\
\hline Calcium, $\mathrm{Ca}^{2+} \mathrm{mg} / \mathrm{L}$ & $56.1 \pm 0.89$ & $50-70$ \\
\hline Magnesium, $\mathrm{Mg}^{2+}, \mathrm{mg} / \mathrm{L}$ & $18.3 \pm 0.21$ & 30 \\
\hline Chlorides, $\mathrm{Cl}^{-}, \mathrm{mg} / \mathrm{L}$ & $33.9 \pm 0.19$ & $50-70$ \\
\hline Sulphates, $\mathrm{SO}_{4}{ }^{2-}, \mathrm{mg} / \mathrm{L}$ & $60.0 \pm 0.57$ & $50-70$ \\
\hline Total hardness of water, mg-eq./L & $4.2 \pm 0.06$ & $5-7$ \\
\hline
\end{tabular}

Regime and dynamics of sulfate ions $\mathrm{SO}_{4}{ }^{2-}$ is in direct proportion to the concentration of calcium ions $\mathrm{Ca}^{2+}$, because their presence may form soluble $\mathrm{CaSO}_{4}$. The smoothed seasonal dynamics of concentrations of sulfate ions and calcium in the cooling pond of Zaporizhzhya NPP indicates their saturated equilibrium amount.

The ecological state of any natural or artificial water object, including the cooling pond of Zaporizhzhya NPP, is determined not only by the state of the gas regime and the mineralization of water, but also by the degree of its trophy, which mostly depends on nutrient content. Its concentration and dynamics of water mainly depends on the intensity of water body processes.

Biogenic elements, mainly compounds of nitrogen and phosphorus, are the most important indicators of the sanitary and ecological state of reservoirs. A typical feature of the regime of dissolved mineral nitrogen compounds in the water of the cooling pond of Zaporizhzhya NPP is the constant presence of its three forms: nitrite $\left(\mathrm{NO}_{2}{ }^{-}\right)$, nitrate $\left(\mathrm{NO}_{3}{ }^{-}\right)$, and ammonium ions $\left(\mathrm{NH}_{4}{ }^{+}\right)$. The maximal levels of nitrates and phosphates are noted in the winter, and the minimum ones are in the summer, due to the active consumption of them by hydrobionts in the growing season (Table 3 ). 
Table 3. The contents of nutrients and organic substances in water of the cooling pond of Zaporizhzhya NPP

\begin{tabular}{|c|c|c|}
\hline Name of the indicator, units of measurement & Measured value & National Standard [12; 13] \\
\hline Ammonium nitrogen, $\mathrm{mg} / \mathrm{L}$ & $0.30 \pm 0.021$ & 1.0 \\
\hline Nitrite nitrogen, $\mathrm{mg} / \mathrm{L}$ & $0.03 \pm 0.004$ & 0.1 \\
\hline Nitrate nitrogen, $\mathrm{mg} / \mathrm{L}$ & $2.37 \pm 0.06$ & no more than 2.0 \\
\hline Phosphate phosphorus, $\mathrm{mg} / \mathrm{L}$ & $0.32 \pm 0.05$ & 0.5 \\
\hline Permanganate oxidability, $\mathrm{mgO} / \mathrm{L}$ & $4.32 \pm 0.28$ & 15.0 \\
\hline Biochemical oxygen demand $\left(\mathrm{BOD}_{5}\right), \mathrm{mgO}_{2} / \mathrm{L}$ & $2.68 \pm 0.31$ & 3.0 \\
\hline
\end{tabular}

However, the seasonal dynamics of the content of biogenic elements in the water is smoothed, because their concentrations depend on the amount of wastewater from the treatment facilities. Given the impact of both natural and anthropogenic factors, there were not significant fluctuations in the contents of nutrients (particularly phosphates) during the year.

The values of permanganate oxidability of water are low and indicate a small amount of easily oxidized organic compounds in the reservoir. The indicator $\mathrm{BOD}_{5}$ is an indicator of the content of easily accessible organic, which is rapidly oxidized.

Monitoring the water quality for a number of pollutants revealed the presence of oil products, lead and cadmium in small concentrations that do not exceed the MAC. The content of manganese is 2 MACs, zinc is 4 MACs, copper is 20 MACs according to the fishery standard (Fig. 2).

Bottom sediments are an active abiotic component of aquatic ecosystems, which can concentrate various chemicals, including toxic metals. Thus, the features of the accumulation, migration and transformation of toxic metals in hydro ecosystems should be studied with special attention, since most of these elements are toxic and can cause disturbance of physiological functions of hydrobionts. It should be noted that in contrast to organic matter, metals are not capable to destruction and, after getting into the reservoir, they extract very slowly. That is why it is important to know the features of accumulation of these substances in the bottom sediments and the processes and factors that influence of them desorption from these substrates. The adsorption of metals by bottom sediments should not be considered as an irreversible process, since the imbalance in the "bottom sediments - water" system is often accompanied by the release of this group of components and their entry into the aquatic environment [19].

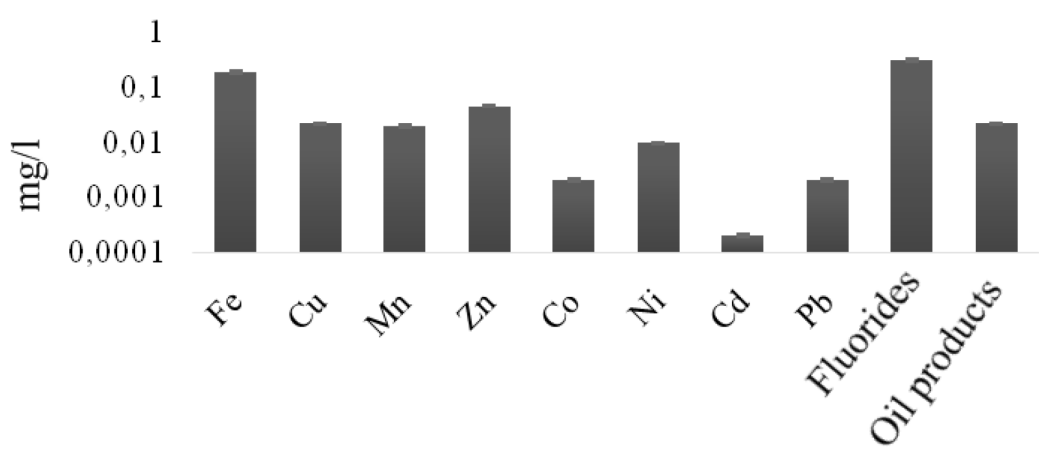

Figure 2. The contents of specific toxic substances in water of the cooling pond of Zaporizhzhya NPP

The most intensive toxic metals accumulate in clayey silt sediments of deep zones with a high content of organic matter in heat sink, as they are characterized by high sorption capacity [20].

Analysis of the composition of the bottom sediments showed that the samples we selected in the reservoir-coolers were dominated by precipitated sand $(60 \%)$. About $30 \%$ of bottom sediments are represented by medium and fine grained sands, and almost $10 \%$ by mud. Previously, it was found that sandy bottom sediments contain up to $1 \%$ of organic matter, silted sand $-4-7 \%$ and silt $-13-15 \%[21]$. 
The content of toxic metals in the bottom sediments of the cooling pond depended on the type of bottom sediments (Fig. 3).

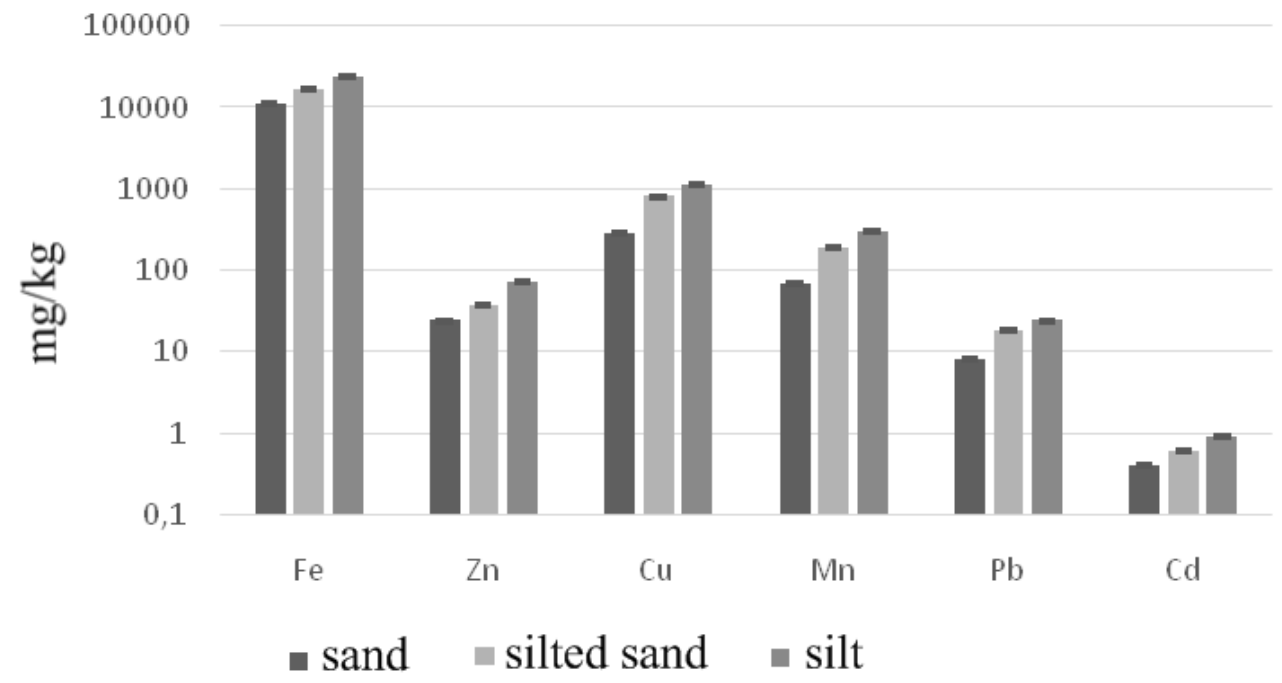

Figure 3. The contents of toxic metals in the bottom sediments at the cooling pond of Zaporizhzhya NPP

The minimum gross content of all investigated metals was observed in sandy sediments, and the maximum one - in silted sediments, characterized by high concentration of organic matter. In such areas, they are deposited both suspended substances of allochthonous origin, entering the cooling pond with domestic and sewage water and fertilizers, and on the other hand, suspended natural organic matter of autochthonous origin, as dead remains of higher water vegetation and phytoplankton. A number of authors previously obtained similar data $[21 ; 22]$.

Analysis of the data shows that the concentration of iron was less in the bottom sediments of the sand type by $34-54 \%$, zinc - by $54-66 \%$, copper - by $65-75 \%$, manganese - by $63-77 \%$, lead by $56-67 \%$ and cadmium - by $33-56 \%$ compared to silted sediments. Consequently, it is possible to assume that the most dangerous ones in case of possible deterioration of water quality are muddy bottom sediments that accumulate toxic metals.

To characterize the processes occurring in the reservoir, the bottom accumulation coefficient (BAC) index was determined that takes into account the ability of toxic metals to accumulate in the bottom sediments (Fig. 4).

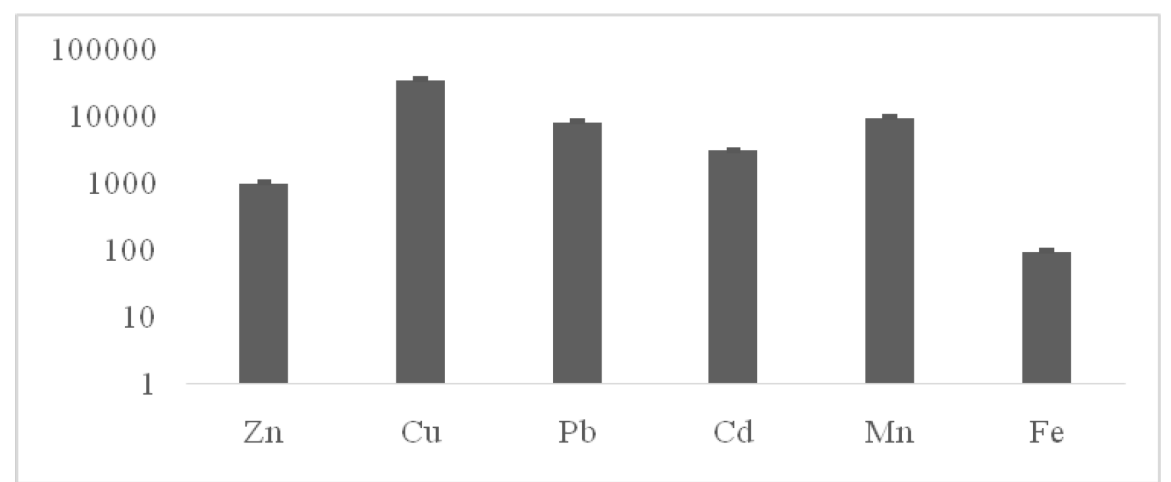

Figure 4. Average values of the bottom accumulation coefficient (BAC) at the cooling pond of Zaporizhzhya NPP

The analysis of the results showed that the coefficients of bottom accumulation of toxic metals varied widely. The BAC indicates a long-term accumulation of the investigated toxic substances in the upper layer of the bottom sediments and the chronic ecosystem pollution, which indicates that the degree of anthropogenic pollution exceeds the level of the self-cleaning ability of the aquatic ecosystem. 
The physical and chemical regime of the water environment of the Zaporizhzhya NPP cooling pond, which is characterized by strong thermal load, promotes the removal of toxic metals from the water environment and their accumulation in the bottom sediments, as evidenced by high values of BAC. However, the hydroecological situation in the reservoir will not lead to significant secondary pollution of the ecosystem of the reservoir.

The maximum BAC for copper is determined, which is due to the high content of this element in the surface layer of sediments. Previously, the pollution of the whole ecosystem of the ZNPP cooling pond by copper compounds was detected, which was associated with the technological process at the NPP [21]. At the present stage, there is a decrease in the average concentration of copper in bottom sediments of the cooling pond by $38 \%$.

As a result of the environmental assessment of the relevant categories of water quality of the surface water of the object it was found that the water of cooling pond of Zaporizhzhya NPP is fresh hypohaline by the criteria of mineralization, and belongs to the quality class I and category 1 . The total contents of the main ions in water, the concentrations of chloride and sulfate ions also corresponded to category 1 by the classification of the quality of fresh hypohaline and oligohaline waters according to the criteria of contamination by the components of the salt composition [10; 15]. The ecological classification by the average annual criteria of hydrogen index $\mathrm{pH}$ and dissolved oxygen can characterize water as "good" - class II, category 3 (Table 4).

Table 4. Classification of water quality in the cooling pond of Zaporizhzhya NPP by trophicsaprobiological (ecological and sanitary) criteria

\begin{tabular}{|c|c|c|c|}
\hline Indicators, units of measure & $\begin{array}{l}\text { Measured values, } \\
\frac{\min -\max }{\text { average }}\end{array}$ & $\begin{array}{c}\text { National Standard } \\
\text { values }[14 ; 15]\end{array}$ & Class, category of water quality \\
\hline \multicolumn{4}{|c|}{ Oxygen regime } \\
\hline Dissolved oxygen, $\mathrm{mg} \mathrm{O}_{2} / \mathrm{L}$ & $\frac{6.4-7.5}{7.1}$ & $7.1-7.5$ & II class ("good"), 3 category \\
\hline \multicolumn{4}{|c|}{ Hydrophysical and general hydrochemical indices } \\
\hline Suspended solid, mg/L & $<5$ & $<5$ & I class ("high"), 1 category \\
\hline Transparency, $\mathrm{m}$ & $>1.50$ & $>1.50$ & I class ("high"), 1 category \\
\hline $\mathrm{pH}$ & $\frac{4.3-9.45}{8.05}$ & $\frac{6.5-6.6}{8.0-8.1}$ & II class ("good"), 3 category \\
\hline \multicolumn{4}{|c|}{ Nitrogen contents } \\
\hline Ammonium nitrogen, $\mathrm{mgN} / \mathrm{L}$ & $\frac{0.29-0.30}{0.30}$ & $0.21-0.30$ & II class ("good"), 3 category \\
\hline Nitrite nitrogen. mgN/L & $\frac{0.002-0.005}{<0.003}$ & $0.002-0.005$ & II class ("good"), 2 category \\
\hline Nitrate nitrogen, $\mathrm{mgN} / \mathrm{L}$ & $\frac{0.5-3.88}{2.16}$ & $1.01-2.50$ & IV class ("poor"), 6 category \\
\hline \multicolumn{4}{|c|}{ Phosphorus content } \\
\hline $\begin{array}{c}\text { Phosphorus phosphates, } \\
\mathrm{mgP} / \mathrm{L}\end{array}$ & $\frac{0.27-0.40}{0.30}$ & $0.201-0.300$ & IV class ("poor"), 6 category \\
\hline \multicolumn{4}{|c|}{ Organic matter contents } \\
\hline $\begin{array}{c}\text { Permanganate oxidability, } \\
\mathrm{mgO} / \mathrm{L}\end{array}$ & $\frac{3.0-5.0}{4.32}$ & $3.0-5.0$ & II class ("good"), 2 category \\
\hline $\mathrm{BOD}_{5}, \mathrm{mgO}_{2} / \mathrm{L}$ & $\frac{2.2-4.0}{2.68}$ & $2.2-4.0$ & III class ("moderate"), 4 category \\
\hline
\end{tabular}

The content of ammonia and nitrite nitrogen is not high and corresponds to class II of water quality, 3 and 2 categories respectively. At the same time, the contents of nitrate nitrogen and phosphorus phosphates in water of the cooling pond of Zaporizhzhya NPP belong to the IV class, and 6 category of "bad, dirty water". 
Region, Ukraine

By the criterion of permanganate oxidability, the quality of water in the cooling pond belongs to the class II, category 2. The value of the $\mathrm{BOD}_{5}$ index determines the quality of water corresponding to the class III, and the category 4 as "satisfactory".

The water quality assessment by contents of some specific toxic pollutants was done (Table 5).

Table 5. Classification of water quality in the cooling pond of Zaporizhzhya NPP according to the criteria of specific toxic factors

\begin{tabular}{|c|c|c|c|}
\hline Indicators, units of measure & $\begin{array}{c}\text { Measured values, } \\
\frac{\min -\text { max }}{\text { average }}\end{array}$ & $\begin{array}{c}\text { National Standard } \\
\text { values }[14 ; 15]\end{array}$ & $\begin{array}{c}\text { Class, category of water } \\
\text { quality }\end{array}$ \\
\hline Iron total (basic scale), $\mu \mathrm{g} / \mathrm{L}$ & $\frac{170-180}{180}$ & $101-500$ & III class, 4 category \\
\hline Cadmium, $\mu \mathrm{g} / \mathrm{L}$ & 0,2 & 0,2 & II class, 3 category \\
\hline Copper, $\mu \mathrm{g} / \mathrm{L}$ & $\frac{10-25}{21}$ & $11-25$ & III class, 5 category \\
\hline Zinc, $\mu \mathrm{g} / \mathrm{L}$ & $\frac{2-5}{2}$ & $21-50$ & III class, 4 category \\
\hline Lead, $\mu \mathrm{g} / \mathrm{L}$ & $\frac{6-10}{9.4}$ & $2-5$ & II class, 2 category \\
\hline Nickel, $\mu \mathrm{g} / \mathrm{L}$ & $\frac{10-25}{19}$ & $6-10$ & II class, 3 category \\
\hline Manganese, $\mu \mathrm{g} / \mathrm{L}$ & $\frac{201-500}{300}$ & $201-500$ & II class, 2 category \\
\hline Fluorides, $\mu \mathrm{g} / \mathrm{L}$ & $\frac{10-25}{21}$ & $10-25$ & III class, 5 category \\
\hline Oil products, $\mu \mathrm{g} / \mathrm{L}$ & & & II class, 2 category \\
\hline
\end{tabular}

All levels of oil products, lead and manganese satisfied to class II, category 2 of quality as "pure" water. According to the contents of nickel and cadmium, water was classified as "fairly clean" - class II, category 3. Concentrations of iron and zinc determined the III class, and category 4 of quality - "slightly polluted" water. According to the concentrations of copper and fluorides, water in the cooling pond of Zaporizhzhya NPP can be attributed to the class III, and category 5 as "moderately polluted" water.

The obtained data allow to calculate the chemical indices of water quality, among which the index of quality according to the salt composition is equal to "1", the index for environmental sanitary criteria is "3.1", index according to the criteria for the content of specific toxic substances is " 3,3 ". Thus, the value of the average chemical quality index is " 2.5 ", which characterizes the water of the cooling pond of Zaporizhzhya NPP as "good" and "clean".

\section{Conclusions}

The cooling system of Zaporizhzhya Nuclear Power Plant uses the artificial water body (cooling pond). The discharging of heated water to the water body creates a special thermal regime and also the conditions for the formation of specific hydrobiocenoses.

The ecological water quality by most hydrochemical and hydrophysical indices corresponds to the class II, category 3 and is characterized as "fairly clean". But, according to the $\mathrm{BOD}_{5}$ index, the water quality is "satisfactory" (class III, category 4). The contents of nitrate nitrogen and phosphorus phosphate in cooling pond of Zaporizhzhya NPP belong to the class IV, category 6 as "bad, dirty water".

The main specific toxic pollutants are toxic metals (copper, iron, zinc), and fluorides. According to their concentrations in water, ecological characteristics correspond to class III, quality categories 4-5 as "poorly and moderately polluted" water. 
Accumulation of toxic metals in the surface layer of the reservoir bottom sediments depends on their types, the minimal content is found in sandy sediments, and maximal one is in muddy sediments. The possibility of significant secondary water pollution by toxic metals is small under typical for cooling pond of Zaporizhzhya NPP hydrophysical and hydrochemical conditions.

Thus, the estimated value of the average chemical index of environmental quality is " 2.5 ," which describes the water quality in cooling pond of Zaporizhzhya NPP as "good" and "clean" water.

\section{Conflict of Interest}

The authors declare that there is no conflict of interest.

\section{References}

[1] V.I. Osadchy et al., Features of distribution and transformation of chemical compounds in conditions of thermally enriched water (on an example of the cooling pond of the Zaporizhya NPP), Hydrology, Hydrochemistry and Hydroecology. 18 (2010) 143-154. (in Ukrainian).

[2] P.N. Linnik, V.A. Zhezherya. Peculiarities of metals migration in the "bottom sediments -water" system with decreasing $\mathrm{pH}$ and increasing the concentration of fulvic acids, Hydrobiological Journal. 47(5) (2011) 86-101.

[3] V.F. Brekhovskikh, T.N. Kazimiruk, V.D. Kazimiruk, Bottom sediments of the Ivankovo reservoir, Science, Moscow, Russia, 2006. (in Russian).

[4] P.M. Linnik, I.B. Zubenko, Role of bottom sediments in the secondary pollution of aquatic environments by heavy-metal compounds, Lakes \& Reservoirs: Research \& Management. 5(1) (2000) 11-21.

[5] P.N. Linnik, Bottom sediments of reservoirs as a potential source of secondary pollution of the aquatic environment by heavy metal compounds, Hydrobiological Journal. 37(1) (2001) 73-86.

[6] P.N. Linnik, B.I. Nabivanets, Forms of migration of metals in fresh surface waters, Gidrometeoizdat, Leningrad, USSR, 1986. (in Russian).

[7] V. Romanenko et al., Hydroecological safety of nuclear power engineering in Ukraine, Visn. Nac. Akad. Nauk Ukr. 6 (2012) 41-51.

[8] N.B. Angagao et al., Water quality assessment of the South-Eastern part of Lake Lanao, Philippines, International Letters of Natural Sciences. 63 (2017) 34-41.

[9] I.N. Ama et al., Determination of water quality index of selected water bodies in Warri, Delta State, Nigeria, World News of Natural Sciences. 16 (2018) 42-52.

[10] V.D. Romanenko, Methods of hydroecological research of surface water, Kyiv, Ukraine, 2006. (in Ukrainian).

[11] T. Sharamok, T. Ananieva, O. Fedonenko, Environmental status of Kam'yanske reservoir (Ukraine), Ekologia (Bratislava). 36(3) (2017) 281-289.

[12] Ukraine National Standard. GSTU 2284:2010. Live Fish. General technical requirements. General specifications. Derzhspozhyvstandart Ukrainy, Kyiv, 2012. (in Ukrainian).

[13] Ukraine Standard. SOU 05.01-37-385: 2006. Water for fish farms. General requirements and norms. Ministry of Agrarian Policy of Ukraine, Kyiv, 2006. (in Ukrainian).

[14] A.V. Grytsenko et al., Methods of environmental assessment of surface water quality for the respective categories, Ukrainian Research Institute of Environmental Problems, Kharkiv, Ukraine, 2012. (in Ukrainian). 
[15] V.D. Romanenko et al., Methods of environmental assessment of surface water quality according to relevant criteria, Symbol-T, Kyiv, Ukraine, 1998. (in Ukrainian).

[16] V.D. Romanenko et al., Methods of installing and using of environmental standards on quality of surface water and estuaries in Ukraine, Kyiv, Ukraine 2001. (in Ukrainian).

[17] A.A. Protasov et al., Techno-ecosystem of nuclear power plants. Hydrobiology, abiotic factors, ecological assessments, Institute of Hydrobiology of the National Academy of Sciences of Ukraine, Kyiv, Ukraine, 2011. (In Russian).

[18] A.A. Protasov et al., Hydrobiological studies on the techno-ecosystem of the Zaporozhye nuclear power station, Hydrobiological Journal. 49(4) (2013) 75-92.

[19] P.N. Linnik, V.A. Zhezhera, T.P. Zhezhera, Migration of chemical elements in the "bottom sediments-water" system of surface water bodies under the influence of various environmental factors, Ecological Chemistry. 25(4) (2016) 222-240. (in Ukrainian).

[20] V.I. Osadchy, N.M. Mostova, N.M. Osadcha, Estimation of secondary pollution of the water environment of Zaporizhya NPP reservoir-cooler with toxic metals due to diffusion from bottom sediments, Scientific Proceedings of the Ukrainian Research Hydrometeorological Institute. 258 (2009) 128-139. (in Ukrainian).

[21] V.I. Osadchy, N.M. Mostova, L.O. Chernyshova, Patterns of the distribution of toxic metals in the bottom sediments of the cooling water reservoir of Zaporizhya NPP, Scientific Proceedings of the Ukrainian Research Hydrometeorological Institute. 257 (2008) 126-145. (in Ukrainian).

[22] O.A. Lipatnikova et al., Forms of the presence of trace elements in the bottom sediments of the Ivankovo reservoir, Geoecology. Engineering Geology. Hydrogeology. Geocryology. 1 (2014) 37-48. (in Russian). 